\title{
Value Relevance of International Financial Reporting Standard (IFRS) Based Accounting Information: Nigerian Stockbrokers' Perception
}

\author{
Oladele Patrick Olajide $^{1 *}$, Oladele Rotimi ${ }^{2}$ and Ajayi Omobola Monsurat ${ }^{3}$
}

${ }^{1}$ Department of Business Administration, Federal University, Oye-Ekiti, Ekiti State, Nigeria

${ }^{2}$ Department of Accounting, Adekunle Ajasin University, Akungba Akoko, Ondo State, Nigeria

${ }^{3}$ Department of Business Administration, Ekiti State University, Ado-Ekiti, Ekiti State, Nigeria

\begin{abstract}
Value relevance of accounting information is a well-researched market-based accounting research apparently calling for more empirical evidence into the perception of information users in the stock market. Therefore, this study examined the perception of the Nigerian stockbrokers regarding value relevance of International Financial Reporting Standards (IFRSs) based accounting information. The research data were drawn from 121 purposively selected stockbrokers at the Nigerian stock exchange using a Likert scale survey questionnaire and based on the exploratory paradigm. Relative importance index measure showed that earnings, net assets and cash flows from investment ranked first separately as critical variables while operating income, the book value of equity and net cash flows at the year-end ranked least accounting data for each statement respectively. Evidence from statistical analyses using one way contingency Chi-square test revealed that sampled stockbrokers perceive IFRS disclosure demands present accounting information better than Nigerian Statement of Accounting Standards (SASs). Further tests into the stockbrokers' perception on value relevance of IFRS based income statement, financial position and cash flows statements accounting information showed that all tested accounting data are statistically value relevant. The results imply that accounting disclosure demands/standards drive value relevance more under IFRS regime than under Nigerian SAS. Thus, beyond earnings and book value according to Ohlson price model, value relevance of other accounting data should be explored while other users' perception regarding this course should be investigated and compared in future studies.
\end{abstract}

Keywords: Accounting information; IFRS; SAS; Stockbrokers; Value relevance

\section{Introduction}

The role of accounting information in national and global economic growth cannot be overstretched. As a result, accounting information is expected to be prepared and disclosed with adequate cognisance of qualitative and up-to-date generally accepted accounting standards. Whereas, emergence and subsequent growing adoption of International Financial Reporting Standards (IFRS) by several corporate entities and national economies as a basis for corporate financial reporting is a no longer fresh trend. This suggests that accounting information issued under this accounting standards perhaps would possess more qualitative and informative features to its users over the one issued based on other national or religion based accounting standards.

Accounting information as conveyed to the public through periodic audited financial reports should unveil fundamentals about corporate entities' financial performance and position among others. These accounting data provide the foundation for any economic decision that individuals (especially stock brokers in line with the focus of this study) or other entities intend to make about the firm. Thus, the strength (i.e., relevance and/or faithful representation) of the accounting data in terms of quality of the basis on which accounting information is prepared becomes inviolable.

Value relevance concept is a market-based form of accounting research that seeks to unearth how much change in share value could be explained by issued accounting information such as earnings, the book value of equity etc. According to Barth et al., value relevance test is one approach to operationalize stated criteria of relevance and reliability (or faithful representation) by the standards setters [1]. This implies that value relevance study is of utmost importance to accounting standards setters. Its etymology has been well traced to Ball and Brown's seminar where they argued that newly released useful accounting information will affect efficient capital market [2-4]. That is, when publicly available accounting data are processed by its users, it translates into the share price of listed firms at the stock market. This processing function is usually effected through the act of a folk of professionals otherwise called stockbrokers.

Extant studies have employed Ohlson price model invariantly such as Umoren and Enang and/or its modified forms used by Omokhudu and Ibadin including the introduction of product terms in the model [5-8]. Other studies have employed Easton and Harris return model side-by-side with Ohlson price model as in Alfaraih and Alade et al. [5-11]. Most of these studies obtained their findings based on the secondary data source, using pooled or panel data. Further, Oyerinde made attempt to examine the perception of institutional and individual investors about value relevance with a submission of no significant difference in their perceptions [12].

In September 2010, the federal government of Nigeria issued out a roadmap of convergence from Nigerian GAAP to IFRS, leading to a major directive that all listed firms should file their financial reports in

*Corresponding author: Oladele Patrick Olajide, Department of Business Administration, Federal University, Oye-Ekiti, Ekiti State, Nigeria, Tel: +23433009401; E-mail: otunbagbobaniyi@yahoo.com

Received November 03, 2018; Accepted November 15, 2018; Published November 22, 2018

Citation: Oladele PO, Oladele R, and Ajayi O (2018) Value Relevance of International Financial Reporting Standard (IFRS) Based Accounting Information: Nigerian Stockbrokers' Perception. Int J Account Res 6: 187. doi:10.35248/2472114X.18.6.187

Copyright: (c) 2018 Oladele PO, et al. This is an open-access article distributed under the terms of the Creative Commons Attribution License, which permits unrestricted use, distribution, and reproduction in any medium, provided the original author and source are credited. 
Citation: Oladele PO, Oladele R, and Ajayi O (2018) Value Relevance of International Financial Reporting Standard (IFRS) Based Accounting Information: Nigerian Stockbrokers' Perception. Int J Account Res 6: 187. doi: 10.35248/2472-114X.18.6.187

compliance with IFRS demands with effect from January 2012 financial year-end. This suggests that stock market participants, especially stockbrokers would be expected to trade with IFRS compliant accounting data.

Apparently and in most cases, investors rely on stockbrokers for appropriate investment opportunity open to them at the stock market, informed by available information at their disposal rather than to personally (investors) engage in the process. Farj et al. observed this in Libya with a submission that investors depend mainly on stockbrokers based information in their investment plans [13]. This, therefore, serves as a pointer that there is a need to expand investigation on the value relevance of accounting information issued under IFRS with definite attention on stockbrokers' perception as indispensable users of the information in the stock market.

The above concerns suggest that very rare studies have sought to examine the perception of the immediate users of the accounting information about how well IFRS-based accounting data translate to change in share value especially after the adoption of the perceived more qualitative and informative accounting standards. As a result, this study seeks to find out how well the accounting information issued based on Nigerian Statement of Accounting Standards could be more or less value relevant than IFRS based accounting data or otherwise, based on sampled Nigerian stockbrokers' perception. Other specific goals are to examine income, financial position and cash flow statements accounting information that is most value relevant upon the adoption of IFRS.

\section{Literature Review}

\section{IFRS adoption and Nigerian stock market}

Prior to the emergence of IFRS in April 2001 as globally acceptable language and basis for financial reporting, corporate financial reporting of many countries was based on country or regional generally accepted accounting principles (standards). However, in other to ensure improved qualitative attribute of the financial reports, IFRS and it adoption became a requisite. It is also believed that the accounting standards would provide support for capital market efficiency and as a way of extenuating the effect of possible information asymmetry at the stock market $[14,15]$.

As at 2005, several countries of the world especial in Europe and Asia have migrated to adopting IFRS. Nigeria as a sovereign nation took the queue in September 2010 when the federal government of Nigeria rolled out a roadmap of convergence with IFRS $[16,17]$. Subsequently, the NSE regulator issued out a directive that all listed companies at the stock market should file their financial reports in compliance with IFRS with effect from January 2012. This step was informed by perceived benefits associated with adopting IFRS which include global capital market integration and cross-border listing, enhanced comparability, improved foreign direct investment, high-quality financial reports among others.

Furthermore, there were obviously different forms of similarities and differences between IFRS requirements and Nigerian erstwhile SASs. OR\&C demonstrates a sound grasp of those similarities and dichotomy between the two accounting standards when it stressed that no summary publication can totally do detail justice to many of their differences [17]. This is because when the guidance is alike, there are conspicuous differences in the application capable of impounding material impact on the financial statements. This is a fact exhaling from practice in this regard.
Regarding Nigeria Stock Market, the market came to being as a product of Lagos Stock Exchange incorporated as limited liability company in September 1960 through indigenization decree of 1977 $[18,19]$. The capital market was internationalised by the federal government of Nigeria in 1995 through abrogation of laws that restrained foreign investors from participating in the market. Also, the stock market emerged to create necessary facilities for corporate entities and government to raise funds for growth and development among others.

NSE operational performance reached an all-time All-Share Index (ASI) of $43,031.83$ points in July 2014 and one of the top performing exchanges globally in 2012 [20]. As the second largest financial centre in sub-Saharan Africa, the NSE (2016) record as at December 31,2015 shows total market capitalisation of $\$ 17.00$ trillion ( $\$ 85.29$ billion) comprising equity and bonds markets, 184 listed companies with equities market capitalisation of $\$ 9.86$ trillion ( $\$ 49.46$ billion), representing about $58 \%$ of the total market capitalisation.

Specifically, post-listing demands at the stock market require listed firms to ensure timely release of their information to the stock market. Whereas, the financial report that is expected to be prepared and issued in accordance with generally accepted accounting standards is one of the information. The confidence of users of this accounting information is enhanced through adequate compliance with the required standards by the listed firms. Undoubtedly, this act would translate to change in share value of listed firms as processed by users (in this case, stockbrokers).

\section{Theoretical background}

Efficient market hypothesis (EMH): Efficient market was first defined by Fama in his land-mark empirical analysis of stock market prices with a conclusion that they follow a random walk [21]. The term was eventually described by Fama as a market in which pricesal ways fully reflect available information [22]. Specifically to security market, Scott puts efficient security market as the one where prices of a security traded on that market at all times fully reflect all information that is publicly known about those securities [23]. Although to Grossman efficient market price systems aggregate diverse information perfectly, Sewell (2011) argues adversely on the other hand that the term 'fully' is a fastidious requirement suggesting that no real market could ever be efficient $[24,25]$.

According to Adelegan and Oyerinde central philosophy of efficient market theory is that market responds quickly to new information as a pointer that capital markets are informationally efficient $[12,26]$. Tsalavoutas stress further that market efficiency is all about how information is absorbed and processed by market participants at the stock market [27]. Since accounting information is vital to determining at least informational efficiency of the security market, adoption of supposed (more) informative and qualitative accounting standard (IFRS) would be expected to enhance the quality of accounting data issued under it. This postulation cannot be out rightly unfamiliar to users of accounting information at the stock market. That is, the attributes of different accounting standards which should be expected to impact accounting information differently cannot be strange to users of the accounting data especially stockbrokers in line with this study. As such, it was the proposition of this study that the quality of IFRSbased accounting information should have improved informational efficiency of the stock as translated to firms market value based on stockbrokers' perception. 
Citation: Oladele PO, Oladele R, and Ajayi O (2018) Value Relevance of International Financial Reporting Standard (IFRS) Based Accounting Information: Nigerian Stockbrokers' Perception. Int J Account Res 6: 187. doi: 10.35248/2472-114X.18.6.187

\section{Empirical review}

A number of studies on the value relevance of accounting information have been conducted. For instance, Liu et al. examine the impact of IFRS adoption on accounting quality of 870 Chinese listed firms between 2005 and 2008 using stock price at sixth month after fiscal year-end as the dependent variable in line with Ohlson framework $[5,28]$. The results showed that accounting quality improved with increased value relevance of accounting measures after IFRS adoption in tandem with Chalmers et al. who obtained incremental information content of earnings and book value of Australia listed firms. In like manner, Okafor et al. investigate whether financial information issued under IFRS has incremental value relevance over accounting information issued under Canadian GAAP $[4,29]$. Findings show that accounting information disclosed under IFRS unveils higher price and returns value relevance than accounting information prepared under local GAAP unswervingly with Liu's et al. findings from China [28].

Gjerde et al. employed 145 restatements of accounting information from Norwegian GAAP to IFRS of firms listed on the Oslo Stock Exchange, Norway [30]. The study unearths distinctive finding on the theoretically established incremental information content of the accounting data upon IFRS adoption against that of Liu et al. and Umoren and Enang with a finding indicating little evidence of increased value-relevance after adopting IFRS [6,28]. By using 153 firms and based on Ohlson price valuation model, Tsalavoutas et al. investigate value relevance of combined book value and net income before and IFRS adoption in Greece with a finding that indicates no significant change in the explanatory power of the variables between the two periods [5,27]. The finding was in tandem with Karğın from Turkey who obtained that value relevance of income statement information decrease during IFRS period suggesting a reduced value relevance under the perceived more qualitative accounting standards (i.e., IFRS) [32]. These imply that after IFRS adoption, there is no unanimous submission regarding value relevance using secondary data. Also, there is a need to expand value relevance conjecture under IFRS from accounting information users' perception.

Prior to IFRS adoption in Nigeria, Oyerinde investigates value relevance of accounting data in the Nigerian stock market [12]. Evidence from the primary data used showed that perceptions of institutional and individual investors about the value relevance of accounting information are not significantly different. This empirical finding does not only serve as impetus for sampling the opinion of stockbrokers in this study, but also because investors' economic decision that affects share values at the stock markets are mostly processed and executed through brokers' professional efforts and knowledge while investors might not be fairly accessible for data collection on the other hand.

Stockbrokers are a group of professionals who deal in various forms of stocks at the stock market on behalf of their clients. They could also be regarded as external users of corporate financial reports for economic decision purpose. Their economic knowledge and decision based on publicly available accounting information about each firm inform kind of investment decision they make about each firm which would have a direct consequence on the firm value at the stock market. This is contingent on the fact that stock market participants desire high-quality accounting information to strengthen their confidence in the local or global stock markets [15,34].

Value relevance is one of the most used measures of accounting quality majorly examined through either Ohlson price valuation and/ or Easton and Harris returns models. While Ohlson price model considers share prices as the response variable in the value relevance regression model, Harris and Easton adopt security returns. That is, Ohlson model presents firm value as a linear function of the book value of equity and the present value of expected future abnormal earnings while Harris and Easton's model relate the change in security returns as a function of both current earnings level and change in earnings variables. These models depend majorly on secondary data such as earnings, the book value of equity, and change in earnings etc. which have been well considered in the literature $[5,9]$.

It is however not out of focus to direct empirical attention to investigating the opinion of users of the accounting information in the stock market concerning value relevance upon the adoption of perceived more qualitative accounting standards. This is due to the fact that this accounting information users group have explored and employed accounting information under the two regimes to make a capital investment decision at the market. Thus, similarities and differences between the two different accounting standards based accounting information as well as their informative natures could not be unfamiliar to the stockbrokers. As such, the main objective of this study is to explore the perception of stockbrokers at the NSE regarding value relevance of IFRS-based accounting data over erstwhile Nigerian SASs or otherwise. This study, therefore, proposed the following statistical hypothesis that;

$\mathbf{H}_{01}$ : IFRS disclosure requirements do not present accounting information better than Nigerian SASs

$\mathbf{H}_{02}$ : NSE stockbrokers do not perceive IFRS-based income statement data more value relevant than SAS-based accounting information

$\mathbf{H}_{03}$ : NSE stockbrokers do not perceive IFRS-based financial position statement data more value relevant than SAS-based accounting information

$\mathbf{H}_{04}$ : NSE stockbrokers do not perceive IFRS-based cash flows statement data more value relevant than SAS-based accounting information.

\section{Methodology}

Research methods employed for the study were based on quantitative philosophy and exploratory research design. Likert scale survey questionnaire was employed to elicit data from 121 purposively selected stockbrokers at the Nigerian stock exchange market. The validity of the instrument was enhanced through prior examination and comments from six purposively selected brokers and financial analysts consulted at their various brokerage firms around NSE in Lagos, Nigeria. The reliability test was also performed to unveil internal consistency of the scale employed using Cronbach's Alpha. The results as shown in Table 1 show Cronbach's Alpha value above 0.8 in each case suggesting very good internal consistency of the scale used which provided basis for using items employed under each content of the financial report. These findings are generally below 0.934 Cronbach Alpha reported by Oyerinde although this study conducted the

\begin{tabular}{|l|c|c|}
\hline & Cronbach's Alpha & Number of items \\
\hline Income statement accounting data & 0.917 & 6 \\
\hline $\begin{array}{l}\text { Statement of financial position } \\
\text { accounting data }\end{array}$ & 0.838 & 4 \\
\hline Cash flows statement accounting data & 0.866 & 4 \\
\hline Source: Authors computation, 2018. & & \\
\hline
\end{tabular}

Table 1: Reliability statistics. 
Citation: Oladele PO, Oladele R, and Ajayi O (2018) Value Relevance of International Financial Reporting Standard (IFRS) Based Accounting Information: Nigerian Stockbrokers' Perception. Int J Account Res 6: 187. doi: 10.35248/2472-114X.18.6.187

Page 4 of 7

reliability test based on items under each content of financial report used unlike Oyerinde whose reliability test was based on all the items pooled together [12].

Both descriptive analysis and semi-parametric statistics were performed. The descriptive analysis involved the use of frequency, percentage and mean value including the use of Relative Importance Index (RII).

$$
R I I=\frac{\sum f x}{\sum f} \times \frac{1}{k}
$$

Where;

$\sum f x=$ Total weight given to each attribute by the respondents.

$\sum f=$ Total number of respondents in the sample.

$\mathrm{K}=$ highest weight on the Likert scale; here $\mathrm{k}=4$

One way contingency Chi-square statistic was employed to tests hypotheses stated in this study while the result obtained informed the submission and recommendation of the study.

\section{Results and Discussion}

\section{Data presentation: descriptive analysis}

Table 2 presents the frequency and percentage distribution of the sampled respondents responses to various questionnaire items examined. The respondents work experience results show that most of the stockbrokers (about 76\%) already had over ten (10) years working experience. This is an indication that the respondents were knowledgeable professionals who have been in the business for at least five years before and after IFRS adoption in Nigeria. It also suggests that they should be able to understand how the two accounting standards would have influenced value relevance differently through the accounting information issued for their use in the market.

In respect of item $\mathrm{B} 1$ which seeks to find out whether disclosure requirements under IFRS presents accounting information to make it more value relevant than the one issued under Nigerian SASs, about $48 \%$ and $42 \%$ (i.e., 58 and51) of the respondents strongly agree and agree with this assertion respectively, leaving around $10 \%$ of them undecided or disagree. These results indicate that most of the respondents believe that IFRS adoption could lead to improved quality of accounting information issued under the accounting standards.

Furthermore, items $\mathrm{C} 1$ to $\mathrm{C} 6$ were drawn to obtain the opinion of the brokers regarding value relevance of income statement items to them when valuing firms in the stock market after IFRS adoption. Over $50 \%$ of them perceive that all the six accounting data are value relevant and strongly value relevant under IFRS than under erstwhile SASs. Similar results were obtained regarding the statement of financial position using items D1-D4 and cash flow statement (items E1-E4) accounting data. Nevertheless, a certain proportion of the respondents is indifferent and disagrees with the proposition about value relevance of these data.

\section{Relative importance index statistics}

Since descriptive statistics results generally showed that the stockbrokers perceive all tested accounting data under IFRS are more value relevant at the stock market, it becomes necessary to unearth how the accounting figures under each of the three contents of financial statement are relatively important. According to Johnson and LeBreton relative importance seeks to uncover proportionate contribution of

\begin{tabular}{|c|c|c|c|c|c|c|c|}
\hline $\mathrm{S} / \mathrm{N}$ & Items & $1-5$ years & $6-10$ years & $11-15$ years & $16-20$ years & Above 20 years & Total Freq $(\%)$ \\
\hline \multirow[t]{3}{*}{ A1 } & \multirow[t]{3}{*}{ Respondents Work Experience } & $9(7 \%)$ & $21(17 \%)$ & $37(31 \%)$ & $24(20 \%)$ & $30(25 \%)$ & $121(100)$ \\
\hline & & Strongly Disagree & Disagree & Undecided & Agree & Strongly Agree & \\
\hline & & 1 & 2 & 3 & 4 & 5 & \\
\hline \multirow[t]{2}{*}{ B1 } & \multirow{2}{*}{$\begin{array}{c}\text { IFRS disclosure demands presents } \\
\text { Accounting information better than } \\
\text { that of SASs }\end{array}$} & 0 & $3(3 \%)$ & $9(7 \%)$ & $51(42 \%)$ & $58(48 \%)$ & $121(100)$ \\
\hline & & $\begin{array}{l}\text { Strongly } \\
\text { Irrelevant }\end{array}$ & Irrelevant & Moderately Relevant & Relevant & $\begin{array}{l}\text { Strongly } \\
\text { Relevant }\end{array}$ & \\
\hline $\mathrm{C} 1$ & Turnover & 0 & $3(3 \%)$ & $15(12 \%)$ & $60(50 \%)$ & $43(35 \%)$ & \\
\hline $\mathrm{C} 2$ & Operating Income (OI) & $3(3 \%)$ & $6(5 \%)$ & $15(12 \%)$ & $54(45 \%)$ & $43(35 \%)$ & \\
\hline $\mathrm{C} 3$ & Net Operating Income (NOI) & 0 & $6(5 \%)$ & $12(10 \%)$ & $63(52 \%)$ & $40(33 \%)$ & \\
\hline $\mathrm{C} 4$ & Profit After Tax (PAT) & $3(3 \%)$ & $6(5 \%)$ & $6(5 \%)$ & $51(42 \%)$ & $55(45 \%)$ & \\
\hline $\mathrm{C} 5$ & Earnings per Share (EPS) & 0 & $3(3 \%)$ & $12(10 \%)$ & $54(45 \%)$ & $52(43 \%)$ & \\
\hline $\mathrm{C} 6$ & Dividend per Share (DPS) & 0 & $6(5 \%)$ & $12(10 \%)$ & $54(45 \%)$ & $49(40 \%)$ & \\
\hline D1 & Total Assets (TA) & 0 & 0 & $6(5 \%)$ & $67(55 \%)$ & $48(40 \%)$ & \\
\hline D2 & Net Assets (NA) & 0 & 0 & $3(2 \%)$ & $70(58 \%)$ & $48(40 \%)$ & \\
\hline D3 & Book Value of Equity (BE) & 0 & $3(2 \%)$ & $15(12 \%)$ & $60(50 \%)$ & $43(36 \%)$ & \\
\hline $\mathrm{D} 4$ & Total Liability (TL) & 0 & 0 & $18(15 \%)$ & $49(40 \%)$ & $54(45 \%)$ & \\
\hline $\mathrm{E} 1$ & $\begin{array}{l}\text { Net Cash Flows from Operation } \\
\text { (NCFO) }\end{array}$ & 0 & 0 & $12(10 \%)$ & $64(53 \%)$ & $45(37 \%)$ & \\
\hline E2 & $\begin{array}{l}\text { Net Cash Flows on Investment } \\
\text { (NCFI) }\end{array}$ & 0 & 0 & $9(7 \%)$ & $67(54 \%)$ & $45(37 \%)$ & \\
\hline E3 & $\begin{array}{l}\text { Net Cash flows on Financing } \\
\text { (NCFF) }\end{array}$ & 0 & 0 & $12(10 \%)$ & $70(58 \%)$ & $39(32 \%)$ & \\
\hline E4 & $\begin{array}{l}\text { Net Cash and Cash equivalent } \\
\text { (NCFend) }\end{array}$ & 0 & $6(5 \%)$ & $9(7 \%)$ & $64(53 \%)$ & $42(35 \%)$ & \\
\hline
\end{tabular}

Table 2: Distribution of the respondents responses to the questionnaire items. 
Citation: Oladele PO, Oladele R, and Ajayi O (2018) Value Relevance of International Financial Reporting Standard (IFRS) Based Accounting Information: Nigerian Stockbrokers' Perception. Int J Account Res 6: 187. doi:10.35248/2472-114X.18.6.187

each parameter/predictor. The RII results are presented and concisely discussed under each of the following subsections [34].

RII of Income statement accounting data: As presented in Table 3 , earnings per share (EPS) is ranked as the most value relevant income statement accounting data (RII $=0.08562)$ followed by profit after tax $(\mathrm{RII}=0.8463)$ based on the respondents perception while operating income $(\mathrm{RII}=0.8116)$ coming as the least value relevant among the examined items. This might possibly be because earnings potential of a listed firm drives investors' investment decision about the firm, and more reason Ohlson model considers earnings as one of the explanatory factors of change in share values.

RII of financial position statement accounting data: Table 4 showcases RII results of value relevant of the tested statement of financial position accounting information. Net assets $(\mathrm{RII}=0.8744)$ was perceived by the respondents as the most relatively important statement of financial position that influences share value in the stock market followed by total assets (RII $=0.8694)$ while total liability (0.8364) coming as the least important. This finding confirms the pragmatic disposition of shareholders regarding the security of their investment in the entity in the event of liquidation. That is, investors tend to assess the value of an entity at the stock market mostly based on its book value of equity or net worth.

RII of cash flows statement accounting data: As touching cash flows statement accounting information items, the stockbrokers perceived that net cash flows from investing activities (RII=0.8595) is the most important cash flows accounting data that drives share value at the NSE. This is marginally followed by net cash flows from operating activities (RII=0.8546). Net cash and cash flows $(\mathrm{RII}=0.8347)$ at the year-end ranked the least accounting data in this regard perhaps as a result of the fact that it is built up of cash from various business activities (Table 5).

\section{Chi-square test results and test of hypotheses}

In a bid to test perception of the stockbrokers regarding the possible ability of IFRS disclosure demands to present accounting information issued under the standards better than Nigerian SASs hypothetically, first null hypothesis was framed.

$\mathbf{H}_{01}$ : IFRS disclosure requirements do not present accounting information better than Nigerian SASs.

One way contingency chi-square test was performed. The result as presented in Table 6 based on the perception of the stockbrokers shows that IFRS disclosure requirements present accounting information better than that of Nigerian Accounting Standards (SASs) since statistical significance was obtained as a p-value less than 0.01 .

$\mathbf{H}_{02}$ : NSE stockbrokers do not perceive IFRS-based income statement data more value relevant than SAS-based accounting information.

Further, the second proposition was made to find out whether the Nigerian stock market brokers perceive IFRS-based income statement accounting data more value relevant than erstwhile Nigerian SAS-based accounting information. The test result based on one-way contingency chi-square as shown in Table 7 revealed that all the tested accounting data were significant statistically $(\mathrm{p}$-value $<0.01)$. This suggests that stockbrokers perceive all the accounting information as part of bases

\begin{tabular}{|c|c|c|c|c|c|c|c|c|c|c|}
\hline & $\begin{array}{l}\text { Strongly } \\
\text { Irrelevant }\end{array}$ & Irrelevant & $\begin{array}{c}\text { Moderately } \\
\text { Relevant }\end{array}$ & Relevant & $\begin{array}{l}\text { Strongly } \\
\text { Relevant }\end{array}$ & & & & & \\
\hline & 1 & 2 & 3 & 4 & 5 & $\Sigma \mathbf{f}$ & $\Sigma f x$ & Mean & RII & Ranking \\
\hline Turnover & 0 & 3 & 15 & 60 & 43 & 121 & 506 & 4.181 & 0.836 & $4^{\text {th }}$ \\
\hline OI & 3 & 6 & 15 & 54 & 43 & 121 & 491 & 4.057 & 0.811 & $6^{\text {th }}$ \\
\hline NOI & 0 & 6 & 12 & 63 & 40 & 121 & 500 & 4.132 & 0.826 & $5^{\text {th }}$ \\
\hline PAT & 3 & 6 & 6 & 51 & 55 & 121 & 512 & 4.231 & 0.846 & $2^{\text {nd }}$ \\
\hline EPS & 0 & 3 & 12 & 54 & 52 & 121 & 518 & 4.281 & 0.856 & $1^{\text {st }}$ \\
\hline DPS & 0 & 6 & 12 & 54 & 49 & 121 & 509 & 4.206 & 0.841 & $3^{\text {rd }}$ \\
\hline
\end{tabular}

Source: Authors computation, 2018.

Table 3: RII results of income statement items

\begin{tabular}{|c|c|c|c|c|c|c|c|c|c|c|}
\hline & $\begin{array}{l}\text { Strongly } \\
\text { Irrelevant }\end{array}$ & Irrelevant & $\begin{array}{c}\text { Moderately } \\
\text { Relevant }\end{array}$ & Relevant & $\begin{array}{l}\text { Strongly } \\
\text { Relevant }\end{array}$ & & & & & \\
\hline & 1 & 2 & 3 & 4 & 5 & $\Sigma f$ & $\Sigma f x$ & Mean & RII & Ranking \\
\hline TA & 0 & 0 & 6 & 67 & 48 & 121 & 526 & 4.347 & 0.869 & $2^{\text {nd }}$ \\
\hline NA & 0 & 0 & 3 & 70 & 48 & 121 & 529 & 4.371 & 0.874 & $1^{\text {st }}$ \\
\hline BVE & 0 & 3 & 15 & 60 & 43 & 121 & 506 & 4.181 & 0.836 & $4^{\text {th }}$ \\
\hline TL & 0 & 0 & 18 & 49 & 54 & 121 & 520 & 4.297 & 0.859 & $3^{\text {rd }}$ \\
\hline
\end{tabular}

Source: Authors computation, 2018.

Table 4: RII results of statement of financial position items.

\begin{tabular}{|c|c|c|c|c|c|c|c|c|c|c|}
\hline & $\begin{array}{l}\text { Strongly } \\
\text { Irrelevant }\end{array}$ & Irrelevant & $\begin{array}{c}\text { Moderately } \\
\text { Relevant }\end{array}$ & Revel. & $\begin{array}{l}\text { Strongly } \\
\text { Relevant }\end{array}$ & & & & & \\
\hline & 1 & 2 & 3 & 4 & 5 & $\Sigma f$ & $\Sigma f x$ & Mean & RII & Ranking \\
\hline NCFO & 0 & 0 & 12 & 64 & 45 & 121 & 517 & 4.2727 & 0.854 & $2^{\text {nd }}$ \\
\hline NCFI & 0 & 0 & 9 & 67 & 45 & 121 & 520 & 4.2975 & 0.859 & $1^{\text {st }}$ \\
\hline NCFF & 0 & 0 & 12 & 70 & 39 & 121 & 511 & 4.2231 & 0.844 & $3^{\text {rd }}$ \\
\hline NCFend & 0 & 6 & 9 & 64 & 42 & 121 & 505 & 4.1736 & 0.834 & $4^{\text {th }}$ \\
\hline
\end{tabular}

Table 5: RII results of cash flows statement items. 
Citation: Oladele PO, Oladele R, and Ajayi O (2018) Value Relevance of International Financial Reporting Standard (IFRS) Based Accounting Information: Nigerian Stockbrokers' Perception. Int J Account Res 6: 187. doi: 10.35248/2472-114X.18.6.187

Page 6 of 7

\begin{tabular}{|l|c|c|}
\hline & Chi-square & df \\
\hline IFRS disclosure demands present Accounting information better than that of SASs & $79.165^{\text {a }}$ & 3 \\
\hline Source: Authors Computation, 2018. & 0.000 & 3 \\
\hline
\end{tabular}

Table 6: Chi-square test summary of IFRS demands' presenting accounting data better.

\begin{tabular}{|c|c|c|c|c|}
\hline Items & $\chi^{2}$ & df & P-value & Status \\
\hline Turnover & $66.868^{a}$ & 3 & 0.000 & Significant \\
\hline Operating income & $87.058^{b}$ & 4 & 0.000 & Significant \\
\hline Net operating income & $69.050^{\mathrm{a}}$ & 3 & 0.000 & Significant \\
\hline Profit after tax & $114.826^{b}$ & 4 & 0.000 & Significant \\
\hline Earnings per share & $69.843^{a}$ & 3 & 0.000 & Significant \\
\hline Dividend per share & $60.719^{a}$ & 3 & 0.000 & Significant \\
\hline \multicolumn{5}{|l|}{ Source: Authors Computation, 2018.} \\
\hline $\begin{array}{l}0 \text { cells }(0.0 \%) \text { have expected frequencies } \\
0 \text { cells }(0.0 \%) \text { have expected frequencies }\end{array}$ & $\begin{array}{l}\text { pected c } \\
\text { pected c }\end{array}$ & 0 . & & \\
\hline
\end{tabular}

Table 7: Chi-square test summary of value relevance of income statement accounting data.

\begin{tabular}{|c|c|c|c|c|}
\hline Items & $\chi^{2}$ & df & P-value & Status \\
\hline Total assets & $48.314^{\mathrm{a}}$ & 2 & 0.000 & Significant \\
\hline Net assets & $57.835^{\mathrm{a}}$ & 2 & 0.000 & Significant \\
\hline Book value equity & $66.868^{\mathrm{b}}$ & 3 & 0.000 & Significant \\
\hline Total liability & $18.860^{\mathrm{a}}$ & 2 & 0.000 & Significant \\
\hline \multicolumn{5}{|l|}{ Source: Authors Computation, 2018.} \\
\hline $\begin{array}{l}{ }^{a} 0 \text { cells }(0.0 \%) \text { have expected frequenci } \\
{ }^{\circ} 0 \text { cells }(0.0 \%) \text { have expected frequenci }\end{array}$ & $\begin{array}{l}\text { bected } c \\
\text { pected c }\end{array}$ & $\begin{array}{l}40.3 ; \\
30.3\end{array}$ & & \\
\hline
\end{tabular}

Table 8: Chi-square test summary of value relevance of statement of financial position accounting data.

\begin{tabular}{|c|c|c|c|c|}
\hline Items & $\chi^{2}$ & df & P-value & Status \\
\hline Net cash flows from operation & $34.331^{\mathrm{a}}$ & 2 & 0.000 & Significant \\
\hline Net cash flows on investment & $42.512^{\mathrm{a}}$ & 2 & 0.000 & Significant \\
\hline Net cash flows on financing & $41.769^{a}$ & 2 & 0.000 & Significant \\
\hline Net cash and cash equivalent & $76.587^{b}$ & 3 & 0.000 & Significant \\
\hline \multicolumn{5}{|l|}{ Source: Authors Computation, 2018.} \\
\hline \multicolumn{5}{|c|}{${ }^{a} 0$ cells $(0.0 \%)$ have expected frequencies less than 5 . The minimum expected cell frequency is 40.3} \\
\hline \multicolumn{5}{|c|}{ '0 cells $(0.0 \%)$ have expected frequencies less than 5. The minimum expected cell frequency is 30.3 . } \\
\hline
\end{tabular}

Table 9: Chi-square test summary of value relevance of cash flows statement accounting data.

that drive their economic decision that could affect firm value in the stock market more under IFRS regime than it was under the erstwhile Nigerian SASs.

$\mathbf{H}_{03}:$ NSE stockbrokers do not perceive IFRS-based financial position statement data more value relevant than SAS-based accounting information.

Null hypothesis three was constructed to test whether NSE stockbrokers do not perceive IFRS-based financial position statement data more value relevant than SAS-based accounting information. Four accounting data were drawn and tested. All the four were statistically significant ( $p$-value $<0.01)$ as indicated in Table 8 , suggesting that stockbrokers perceive IFRS-based accounting data do not only contribute to change in share value at the stock market but demonstrate higher value relevance than accounting data issued under SASs.

$\mathbf{H}_{04}$ : NSE stockbrokers do not perceive IFRS-based cash flows statement data more value relevant than SAS-based accounting information.

Hypothesis four seeks to observe whether NSE stockbrokers do not perceive IFRS-based cash flows statement data more value relevant than SAS-based accounting information. Statistical evidence presented in Table 9 based on one-way contingency chi-square result test on each of the four accounting data examined showed that the proposition is statistically significant at 0.01 levels. The results suggest that this IFRS based accounting information are more value relevant than the one issued under Nigerian SASs.

Succinctly, the above statistical evidence based on perception of Nigerian stockbrokers drawn through survey questionnaire showed that accounting information prepared and issued under IFRS disclosure demands are more value relevant than the one issued under the former Nigerian GAAP (SASs) consistently with existing studies conducted using continuous variables such as Liu et al. Okafor et al. and Chalmers et al. but at variance with Tsalavoutas et al. and Karğın [4,27-34]. Theoretically, the findings also suggest that IFRS-based accounting information improves the informational efficiency of the market. This also implies that the market participants are more informed about the affairs of listed corporate entities through the IFRS-based accounting data issued compare to the one issued under the then Nigerian SASs.

\section{Conclusion and Recommendation}

Drawing from the findings of this study, it is clear that NSE stockbrokers do not only perceive that IFRS disclosure demands and its consequent accounting information are more value relevant than the one issued under erstwhile Nigerian SASs, their perceptions are statistically significant. It is therefore concluded that based on NSE stockbrokers' perception, IFRS-based accounting information are 
Citation: Oladele PO, Oladele R, and Ajayi O (2018) Value Relevance of International Financial Reporting Standard (IFRS) Based Accounting Information: Nigerian Stockbrokers' Perception. Int J Account Res 6: 187. doi: 10.35248/2472-114X.18.6.187

more value relevant than SASs-based accounting data. Consequently, the stock market informational efficiency in this regard is also expected to have improved thereby establishing the relevance of EMH to value relevance concept. This implies that IFRS disclosure demands inform issuance of more informative accounting data that could strengthen stock market efficiency informatively compare to erstwhile Nigerian SASs.

It is therefore recommended that accounting standards setters should ensure issuance of more users supportive IFRSs that could strengthen users' confidence about the content of financial reports. Stock market regulators should also crusade improve compliance with IFRS disclosure demands to enhance results of economic decision of the users at the stock market. Although submission of this perceptionbased value relevance study was meant to document opinion of the accounting information users, there is a need to expand the coverage of the respondent groups (or users of accounting information) considered in this study in the future investigation which could be adduced as a limitation of this study.

\section{References}

1. Barth ME, Beaver WH, Landsman WR (2001) The relevance of the value relevance for financial accounting standard setting: Another view. Journal of Accounting and Economics 31: 77-104.

2. Ball R, Brown $P$ (1968) An empirical evaluation of accounting income numbers. Journal of Accounting Research 6: 159-178.

3. Desoky AM, Mousa GA (2014) The value relevance and predictability of IFRS accounting information: The case of GCC stock markets. International Journal of Accounting and Financial Reporting 4: 215-235.

4. Okafor ON, Anderson M, Warsame H (2016) IFRS and value relevance: Evidence based on Canadian adoption. International Journal of Management Finance 22: 136-160.

5. Ohlson JA (1995) Earnings, book values and dividends in equity valuation Contemporary Accounting Research 11: 661-687.

6. Umoren AO, Enang ER (2015) IFRS adoption and value relevance of financial statements of Nigerian listed banks. International Journal of Finance and Accounting 4: 1-7.

7. Omokhudu OO, Ibadin PO (2015) The value relevance of accounting information: Evidence from Nigeria. Accounting and Finance Research 4: 20-30.

8. Clarkson P, Hanna JD, Richardson GD, Thompson R (2011) The impact of IFRS adoption on the value relevance of book value and earnings. Journal of Contemporary Accounting and Economics 7: 1-17.

9. Easton PD, Harris TS (1991) Earnings as an explanatory variable for returns. Journal of Accounting Research 29: 19-36.

10. Alfaraih M (2009) Compliance with International Financial Reporting Standards (IFRS) and value relevance of accounting information in emerging stock markets: Evidence from Kuwait.

11. Alade ME, Olweny T, Oluoch O (2017) Impact of IFRS adoption on value relevance of earnings and book value of Nigerian listed non-financial firms. European Journal of Business, Economics and Accountancy 5: 53-69.

12. Oyerinde DT (2011) Value-Relevance of Accounting Information in the Nigerian Stock Market.
13. Farj $\mathrm{RMH}$, Jais $\mathrm{MB}$, Isa $\mathrm{AHB}$ (2016) Importance of accounting information to investors in the stock market: A study of Libya. Journal of Economic and Finance 7: 70-79.

14. BoliBok P (2014) The impact of IFRS on the value relevance of accounting data of banks listed on the Warsaw stock exchange. Copernican Journal of Finance and Accounting 3: 33-43.

15. Kothari SP (2000) The role of financial reporting in reducing financial risks in the market. Conference Series-Federal Reserve Bank of Boston 44: 89-102.

16. Edogbanya A, Kamardin H (2014) Adoption of International Financial Reporting Standards in Nigeria: Concept and issues. Journal of Advanced Management Sciences 2: 72-75

17. OR\&C (2011) Similarities and differences: IFRS and Nigerian GAAPs.

18. Osaze EB (2007) The Nigerian capital market in the African and global financial system. Lagos: Bofic Consulting Group.

19. Olowe O, Matthew, O, Fasina F (2011) Nigerian stock exchange and economic development. Manager 14: 14-18.

20. Onyema (2013) The Nigerian Stock Exchange 2013 Market Outlook.

21. Fama EF (1965) The behaviour of stock-market prices. Journal of Business 38: 34-105.

22. Fama EF (1970) Efficient capital markets: A review of theory and empirical work. J Finance 25: 383-417.

23. Scott WR (2009) Financial accounting theory (5th edn.), Toronto: Pearson Pretence Hall.

24. Grossman S (1976) On the efficiency of competitive stock markets where traders have diverse information. J Finance 31: 573-585.

25. Sewell M (2011) History of the efficient market hypothesis.

26. Adelegan OJ (2004) How efficient is the Nigerian stock market? Further evidence. African Review of Money Finance and Banking, pp: 145-155.

27. Tsalavoutas I, Andre P, Evans L (2012) The transition to IFRS and the value relevance of financial statement in Greece. The British Accounting Review 44: 262-277.

28. Liu C, Yao LJ, Hu N, Liu L (2011) The impact of IFRS on accounting quality in a regulated market: An empirical study of China. Journal of Accounting, Auditing and Finance 26: 659-676.

29. Chalmers K, Clinch G, Godfrey JM (2011) Changes in value relevance of accounting information upon IFRS adoption: Evidence from Australia Australian Journal of Management 36: 151-173.

30. Gjerde $\varnothing$, Knivsflå K, Sættem F (2008) The Value-relevance of adopting IFRS Evidence from 145 NGAAP restatements.

31. Tsalavoutas I (2009) The adoption of IFRS by Greek listed companies: Financial statement effects, level of compliance and value relevance.

32. Karğin S (2013) The impact of IFRS on the value relevance of accounting information: evidence form Turkish firms. International Journal of Economics and Finance 5: 71-80.

33. Nobes C, Parker R (2008) Comparative International Accounting (10th ed.) Essex, England: Pearson Education Limited.

34. Johnson JW, LeBreton JM (2004) History and use of relative importance indices in organizational research. Organ Res Methods 7: 238-257. 